\title{
Gamle og nye udtryk for islam i Tunesien: Regimerne og den islamiske
} Radio Zitouna

Af Rikke Hostrup Haugbølle

\begin{abstract}
In 2007 Tunisia's first Islamic radio channel, Radio Zitouna, was launched. The year before, in 2006, a public expression of Islam by the population culminated when Ben Ali and his regime cracked down on women wearing the Islamic veil in public. Same year the regime caught an Islamist group planning an attack on strategic places and the president and therefore described by the regime as terrorists. With a point of departure in the theories presented by studies of the Arab authoritarian regimes it would be obvious to explain the launch of Radio Zitouna as a regime response to a threat against one of its power strongholds, Islam. However, this article widens the perspective of Radio Zitouna and includes other aspects than the relation between the radio station and the regime. Bases on analysis of a number of programmes broadcast from 2007 to 2009 and interviews with the staff at the radio station in 2009 and 2010 the article presents other contexts which do not only link to the current events in Tunisia but rather relates to a broader historical and political context.
\end{abstract}

En råkold eftermiddag i marts 2009 kørte jeg op ad kystvejen i det mondæne kvarter Khartago øst for Tunis med svedige håndflader, bævrende ben og stor koncentration. På bagsædet af taxaen sad min danske kollega og en tunesisk ven, som jeg har kendt gennem mange år, og som jeg vidste, jeg kunne stole $100 \%$ på. Jeg var på vej til mit første besøg på Radio Zitouna, Tunesiens første islamiske radiokanal, der var blevet lanceret i september 2007. Siden midten af 1990'erne havde jeg boet i Tunesien ad flere omgange og oplevet, hvordan venner og bekendte både i Tunis, Hammamet og Douz i syden fortalte, at de fik deres telefoner aflyttet og breve åbnet og blev overvåget. De antog selv, at det var fordi de gik i den lokale moske for at bede. Nu var jeg i Tunis på feltarbejde og havde få dage forinden talt med journalister, der fortalte, hvordan de og deres familier blev overvåget og truet, fordi de ytrede sig kritisk om regimet. Der var således en følelse af, at man aldrig vidste, om der var uønskede, der lyttede med selv i private samtaler både om følsomme emner som islam og politik og generelt. Jeg havde bl.a. talt med journalisterne

(C) Forfatteren og Tidsskrift for Islamforskning, ISSN 1901-9580, publiceret 1-03-2013 
om Radio Zitouna. Når islam var sådan et følsomt emne, som jeg havde oplevet det $\mathrm{i}$ årene indtil nu, hvordan kunne der så lanceres en radiostation, der kun sendte programmer om islam, koranen og hadith? Journalisterne svar var enslydende: Det er da logisk. For Radio Zitouna er ejet af Ben Ali’s svigersøn, så den er jo en del af regimet. Argumentet om de arabiske autoritære regimer og deres ejerskab af centrale og store dele af det private erhvervsliv er centralt hos en række forskere, der var kritiske over for antagelsen af, at liberalisering af de arabiske $\varnothing$ konomier også ville medføre politisk liberalisering og dermed være del af en demokratiseringsproces (Perthes, 2004; Hinnebusch 2006; Heydemann, 2007, se også se Valbjørn, 2007, for en redegørelse for denne debat). Kritikerne argumenterede, at liberaliseringerne tværtimod blev anvendt af regimerne til at styrke egen magt, fordi ejerskab af virksomheder overgik til enten præsidenten selv eller hans nære familie og rådgivere. Også i forhold til Tunesien gjorde dette sig gældende (King, 2003; Hibou, 2006; Erdle, 2010). Da man ikke frit kunne kritisere Ben Alis regime, var det også vanskeligt at undersøge virksomheder og andre aktiviteter, som var ejet af præsidentfamlien. Og her var jeg altså, på vej til en radiostation, der både talte om islam og var ejet af regimet. Med mit mangeårige kendskab til overvågning og undertrykkelse i Tunesien følte jeg, at nærmest opsøgte alvorlige problemer. Men da jeg var i Tunis for at undersøge de nye private radio- og TV stationer, der var blevet lanceret siden en liberalisering af mediesektoren i 2003, var det min holdning, at det ville være et ufuldstændigt studie, hvis jeg ikke i det mindste fors $\varnothing$ gte at inkludere Radio Zitouna, der var interessant, netop fordi den som den eneste af de nye medier kun omhandlede islam.

Frem til lanceringen af Radio Zitouna havde Ben Alis regime stået for en giv-og-tag tilgang i forhold til islams rolle i Tunesien, hvor regimet nogle gange undertrykte islam, andre gange lancrede islam-tiltag. Som Albrecht \& Schlumberger (2004) har påpeget i deres kritiske studier af de arabiske, autoritære regimer, igangsættes sådanne tiltag, når et autoritært regime føler sig truet. Ved selv at lancere organisationer - eller som her medier, der dækker det område, hvorfra en trussel begynder at vokse frem, tager regimet broden af denne trussel, fordi regimet ofte vil have langt flere muligheder og midler for at fremføre holdninger og agendaer på det givne område. Langsomt bliver den nye oppositions-organisation kvalt, så kun regimets budskaber på det givne område når befolknin- 
gen. Var lanceringen af Radio Zitouna et sådant repons fra regimets side på andre islamtiltag i samfundet? Havde det så central en betydning, som både journalister og teorien gjorde gældende, at Radio Zitouna var ejet af Ben Alis svigersøn?

Denne artikel handler om Radio Zitouna. Men den handler langt fra kun om ejerskab og det autoritære regime. Den handler endvidere ikke kun om 2007, hvor Radio Zitouna blev lanceret. Derimod argumenter artiklen for, at Radio Zitouna skal forstås i en langt bredere historisk og politisk kontekst og sættes i relation til en række øvrige politiske og sociale udviklinger. Som det første skaber artiklen derfor en baggrundsforståelse for islams rolle og status i Tunesien under de to præsidenter Habib Bourguiba og Ben Ali. Derefter zoomer artiklen ind på selve Radio Zitouna. Jeg blev meget venligt og åbent mødt af både direktøren og det øvrige personale på Radio Zitouna ved mit første møde, og fra november 2009 til december 2010 besøgte jeg radiostationen fire gange. Jeg havde samtaler med radioens direktør og flere af de ansatte, og havde lejlighed til at følge deres arbejde med forberedelse af programmerne. Derudover lyttede jeg til 25 af de programmer, som Radio Zitouna sendte, og som var tilgængelige på internettet via deres hjemmeside. Med eksempler fra udvalgte programmer suppleret med samtalerne med de ansatte indkredser jeg, hvordan islam blev udtrykt på radiostationen, hvilke strategier, der lå bag radions virke, samt hvilke budskaber man gennem programmerne søgte at udbrede til tuneserne. Helt centralt fremstår bestræbelserne på at bygge bro over det fravær af islam, som Radio Zitounas ansatte oplever, der har været siden landets første præsident, Habib Bourguiba, i 1956 indførte sin fransk-ispirerede sekulariseringspolitik.

\section{Fra "Tunesien skal være sekulært" til "islam er voldelig terrorisme"}

Habib Bourguiba var inden Tunesien selvstændighed i 1956 leder af selvstændighedsbevægelsen, der kæmpede for uafhængighed fra det franske protektorat. Bevægelsen havde mange fremtrædende personer, der ikke alle var politisk og ideologisk enige med Bourguiba, og bevægelsen var splittet på centrale punkter. Særligt kom kampen til at stå mellem den franskuddannede Bourguiba, der havde sit bagland i Tunis og Monastir, og den pan-arabiske Salah Ben Youssef fra Jerba i Sydtunesien, som var ud af en familie med 
mange islamiske lærde (Khlifi, 2005). Netop islam var et af stridspunkterne mellem de to interne fløje, som Bourguiba og Ben Youssef repræsenterede. Bourguiba mente, at islams fremtrædende rolle i forhold til lovgivning og uddannelse var en af årsagerne til, at Tunesien var tilbagestående og ikke havde modernisert sig i samme tempo som de europæiske lande. Hvis Tunesien skulle blive moderne, måtte islam og stat adskilles, og religion måtte spille en meget mere tilbagetrukket rolle. Derudover lagde Bourguiba vægt på Tunesien som én samlet nationalstat og talte om, at alle tunesere i fællesskab måtte stå sammen og bidrage til opbygningen af denne nationalstat (Haugbølle, 2006). Ben Youssef mente derimod, at Tunesien var del af en større arabisk sammenhæng, og at islam var et helt centralt grundlag både kulturelt, historisk og identitetsmæssigt. Bourguibas nære kontakt til Frankrig betød, at franskmændene accepterede delvist tunesisk selvstændighed, og Bourguiba underskrev en aftale trods stor modstand mod dette i Ben Yousseffraktionen (Perkins, 2004). Bourguiba blev udråbt til præsident i det nye selvstændige Tunesien og fremstod dermed også som vinderen i den interne magtkamp i Neo-Destour bevægelsen. Salah Ben Youssef blev dømt til døden i både 1957 og 1958, men det lykkedes ham at flygte først til Tripoli i Libyen og senere til Zürich (Khlifi, 2005). Andre tunesere, der havde bakket op om Ben Youssef blev også forfulgt og undertrykt, ligesom store del af befolkningen på Jerba, hvor Ben Youssef var fra, og andre regioner i det sydøstlige Tunesien, blev særligt overvåget og undertrykt.

Da modstanden fra islamister i egne rækker på denne måde var knust, gennemførte Bourguiba en række reformer, der angik islam. Disse havde til formål dels at sikre, at de islamiske lærde (ulama) og en række andre faggrupper, der hidtil havde haft magt eller indflydelse netop på grund af deres position som islamiske lærde, ikke kunne udgøre en trussel mod Bourguibas magt, og dels at stat og religion blev helt adskilt, hvilket i Bourguibas optik var en forudsætning for at Tunesien kunne moderniseres og nå europæisk niveau. Som led i reformerne blev det historiske og velrenomerede islamiske lærdomscenter ved den store Zitouna Moske og det tilhørende store bibiliotek i Tunis lukket, og islamiske studier blev flyttet til det nye, sekulære universitet, hvor en afdeling for teologi blev oprettet. Stillingerne her blev herefter gennem årtier besat af personer, der havde tæt tilknytning til både Bourguiba- og Ben Ali-regimet. Det islamiske, juridiske system blev 
erstattet med et civilretsligt system, og nye love blev skrevet (Hajji, 2011). Mens størsteparten af de islamiske lærde mistede deres positioner og indflydelse, var der dog også fløje af ulama, som bistod Bourguiba $\mathrm{i}$ at omskrive lovene, så disse ikke var i modstrid eller konflikt med islam (Moore, 1965). Som et led i Bourguibas moderniseringsbestræbelser blev arbejdstiden ikke længere nedsat i ramadanen, og Bourguiba opfordrede tuneserne til, ikke at faste fordi, argumenterede han, det nedsatte evnen til at kæmpe for et nyt, moderne Tunesien (Salem, 1984). Endelig spillede fremstillingen af den tunesiske kvinde en central rolle i Bourguibas reformprojekt. Kvinders påklædning og især brugen af det islamiske hovedtørklæde var for Bourguiba et synligt tegn på landets tilbageståenhed. I hans taler kaldte han tørklædet for "en afskyelig klud" (Moore, 1965:55), som intet havde at gøre med tunesisk kultur, tradition og historie. En lang række reformer blev gennemført af de love, der regulerede kvinders status, ægteskab og arveret. Som Charrad (2001) imidlertid påpeger, blev disse reformer gennemført fra statens og regimets side som "part of a broad program of social transformation pursued by a nationalist movement holding the reins of power" (Charrad, 2011: 112). Reformerne var således ikke et udkomme af krav og ønsker fremsat af de tunesiske kvinder men derimod en del af en regimestrategi. Som en konsekvens af reformerne forsvandt det islamiske tørklæde gradvist fra det tunesiske offentlige rum fra 1956 og i 1981 indførte Bourguiba ved dekretlov et forbud mod at bære tørklæde i offentlige institutioner, kontorer og bygninger. Dette forbud blev først ændret med oprøret i 2011, og således var det yderst sjældent at se kvinder bære det religiøse tørklæde i det offentlige, mens flere former for traditionelle tørklæder var i anvendelse, især blandt ældre kvinder.

I 1980'erne blev det tydeligt, at islam dog stadig var vigtig for befolkningen. Tilslutningen til den da nydannede islamiske bevægelse Mouvement de la Tendence Islamique (MTI), som Ennahda, hed frem til 1989, var konstant tiltagende. Mens oppositionspartierne fra 1978 var undertrykt, og fagbevægelserne lagt ind under Bourguibas regime, fremstod MTI som den eneste bevægelse, der udtrykte befolkningens krav om forbedrede $\emptyset$ konomiske og sociale forhold. Efterhånden som MTI voksede sig større og Rachid Ghannouchi, den ene af de to grundlæggere, fik stadig større lytterskarer på sine turneer rundt om i landet, blev bevægelsen mødt med tilsvarende repressalier og undertrykkelse fra 
Bourguiba-regimet (Perkins, 2004). Forholdet mellem MTI og regimet ledet af en aldrende Bourguiba blev stadig mere anspændt, og som en kulmination afsatte daværende premierminister Ben Ali i november 1987 den da 84-årige Bourguiba fra embedet som præsident. Med henvisning til grundlovens paragraf 57 overtog Ben Ali selv posten som præsident. I de første år udviste Ben Ali nogen grad af vilje til dialog med islamisterne og løslod flere tusinde MTI medlemmer. I det politiske forår, der syntes at være kommet med Ben Alis magtovertagelse, viste MTI, at man var villig til at indgå i en demokratisk proces bl.a. ved at opstille til parlamentsvalget i 1991. Det var i denne sammenhæng at bevægelsen ændrede navn til Hizb Ennahda - som betyder Renæssance Partiet. Men da det blev klart for Ben Ali regimet, at Ennahda stod til at vinde en overvældende sejr ved valget, gennemførtes en klapjagt på både partiets ledere og menige medlemmer. Partiet blev forbudt, og en lang række Ennahda-folk søgte med deres familier i eksil i udlandet, mens mange andre blev fængslet (Waltz, 1986; Boulby, 1988; Allani, 2009) ${ }^{\mathrm{i}}$.

For at konsolidere sin magt havde Ben Ali brug for anerkendele fra USA og EU, da han var helt afhængig af $\varnothing$ konomisk støtte fra disse aktører for at kunne levere de ydelser, som tuneserne krævede, bl.a. bedre veje, hospitalsvæsen og ikke mindst arbejde. Samtidig var borgerkrigen i nabolandet Algeriet brudt ud, hvor islamistiske kræfter var centrale. For Tunesiens andet naboland, Libyen, gjaldt det, at Lockerbie-sagen stadig var frisk i Vestens erindring. Islamister og terrorister syntes i en europæisk optik at præge Nordafrika, og derfor blev der set gennem fingre med Ben Alis hårdhændede fremfærd mod Ennahda, så længe det skabte sikkerhed og stabilitet. Som en konsekvens af både den hjemlige og internationale scene fortsatte Ben Ali derfor sin hårde linie i forhold til især politisk islam. Forbudet fra 1981 mod kvindernes brug af det islamiske tørklæde blev også holdt i hævd. Den undertrykkende og brutale fremfærd mod praktiserende muslimer, samt regimets italesættelse af en altid eksisterende trussel fra ikke nærmere definerede islamistiske grupper betød, at islam ikke blev diskuteret eller udtrykt af tuneserne selv i en offentlig sammenhæng indtil begyndelsen af 2000-tallet.

Samtidig med den hårde linie over for Ennahda og praktiserende muslimer, (re)lancerede regimet andre elementer og perspektiver af islam i årene umiddelbart efter Ben Alis 
tiltrædelse som præsident. Som et eksempel herpå blev kald til bøn som noget nyt indført på statsligt radio og TV. Et andet eksempel er, at Ben Ali i modsætning til Bourguiba gav ramadanen særlig plads og opmærksomhed, idet han bl.a. holdt offentlige taler til nationen i anledning af religiøse højtider. I disse talte ham om, at islam var en del af tunesisk kultur og historie, og han roste de tiltag, der blev gjort under ramadanen, for at holde islamiske traditioner og aktiviteter ved lige. Årlige prisuddelinger til unge talenter inden for koran-recitation blev også etableret. Alle disse tiltag til en repræsentation af islam i det offentlige betød, at Ben Ali for mange tunesere fremstod som mere åben over for islam end Bourguiba havde gjort, trods hans samtidige undertrykkelse af politisk islam.

I 2006, året før Radio Zitouna blev lanceret, blev regimet konfronteret med udfordringer, der angik islam fra flere fronter, og som destabiliserede den hidtidige giv-og-tag politik med hensyn til islam. Den første udfordring angik brugen af det religiøse tørklæde, hijab. Mens tørklædet var så godt som fraværende frem til begyndelsen af 2000-tallet, steg antallet af kvinder i alle aldre, der bar tørklæde offentligt fra det nye årtusindes begyndelse (Kerrou, 2010). Det samme havde været tilfældet i 1980'erne, hvor et stigende udtryk for islam i en ofentlig sammenhæng havde ledt til en bred folkelig opbakning til Ennahda. Regimets erfaring var altså, at en øget bevidsthed om islam i befolkningen kunne blive en trussel mod regimet. I ramadanen i oktober 2006 slog regimet hårdhændet ned på de kvinder, der valgte at trodse forbudet og bar tørklædet offentligt. Kvinderne blev enten stoppet på gaden og beordret at tage tørklædet af, eller "prikket" i de offentlige busser af civile betjente, som førte dem til nærmeste politistation. Her skulle kvinden underskrive en attest, kaldet iltizam, på, at hun aldrig mere ville gå med tørklæde. Stadig flere trodsede dog forbudet. Samtidig begyndte stadig flere mænd at anlægge fuldskæg. Et nyt syn i en tunesisk sammenhæng, der fik mig til at standse op på min vej gennem Tunis var, at så mange særligt mænd begyndte at gå i moskeerne til fredagsbønnen, at der ikke længere var plads inde i moskeerne, så de måtte stå på gaden og foretage bønnen. Dette var i stor kontrast til min erfaring i slutningen af 1990'erne, hvor folk jeg kendte nærmest sneg sig afsted til moskeerne. Nu stod de samme mænd og mange flere i fuld offentlighed og praktiserede islam. Samme år, i december 2006, blev en væbnet, islamistisk gruppe på- 
grebet $\mathrm{i}$ en by 30 kilometer syd for Tunis. Medlemmerne af gruppen udtalte efter anholdelsen, at de ville gøre oprør mod Ben Alis undertrykkende regime gennem væbnet kamp, og flere af gruppens ledende medlemmer havde bånd til den salafistiske Gruppen for Bøn og Kamp. Dette udløste foruroligelse i befolkningen for, om der var en potentiel risiko for terrorangreb i Tunesien. I denne nye kontekst blev Radio Zitouna lanceret i ramadanen i september 2007. I det følgende indkredser jeg gennem analyser af programmer og samtaler med de ansatte, hvordan islam blev udtrykt på Radio Zitouna frem til oprøret i 2010. Undervejs knyttes disse udtryk for islam på radiostationen til den bredere historiske og politiske kontekst.

\section{Nye islam-tiltag: Den islamiske Radio Zitouna}

Radio Zitouna har til huse i en stor, hvid villa ved kystvejen i Khartago, ikke langt fra Ben Alis palads. Taxaen satte mig af på hovedvejen og jeg gik de sidste 50 meter op til den bevæbnede vagt uden for villaen. Jeg hilste venligt og sagde, jeg havde en aftale med radiostationens direktør. Jeg blev straks vist ind i receptionen, som er indrettet i det, der egentlig er stuen i den store villa med to sofaer i mørkegrønt imiteret læder. Her sad jeg ved de fleste af besøgene og ventede, indtil jeg blev vist op til kontorerne indrettet i villaens værelser på 1.-salen eller ud i det lille anneks, hvor programredaktøren og teknikkerne har kontorer. Jeg havde ringet inden dette første møde og aftalt med Kamel Omrane, radioens daglige direktør fra 2007 til 2010, at jeg kunne komme. Kamel Omrane er omkring de 60 år og har en baggrund som professor i arabisk civilisation på universitetet $\mathrm{i}$ Tunis. Han er en kendt akademiker i Tunesien, blandt andet fordi han inden lanceringen af Radio Zitouna var leder af den nationale, statsejede radio. Derudover var Omrane imam ved en af de store moskeer i Tunis, og medlem af Det Øverste Råd for Islam, en instans etableret af Ben Ali i 1988, året efter hans magtovertagelse. Instansen rådgav Ben Ali om religiøse anliggende i bredeste forstand. Omrane havde således et langt og personligt men også professionelt engagement $\mathrm{i}$ islam i Tunesien. I slutningen af december 2010 - under oprøret i Tunesien - forlod Kamel Omrane Radio Zitouna, da han blev udnævnt til minister for religiøse anliggender i forbindelse med den omstrukturering af regeringen, som Ben Ali gennemførte $\mathrm{i}$ et forsøg på at imødekomme demonstranterne kritik af regi-

(C) Forfatteren og Tidsskrift for Islamforskning, ISSN 1901-9580, publiceret 1-03-2013 
met (Murphy, 2011). Ved siden af Kamel Omranes kontor havde radiokanalens meget populære programvært Mohammed Machfar sit kontor. Mohammed Machfar har oprindeligt en universitetsgrad i matematik fra Tunis Universitet men skiftede så spor og påbegyndte sine studier i islam og koranen. Han blev specialisert i koranrecitation og tiltrådte som imam ved nye, store Abedine Moske i Khartago, der åbnede i 2003. Machfar blev både af ansatte på Radio Zitouna og tunesere uden for radiostationen omtalt som sheik Machfar i betydningen islam-kyndig og med reference til hans universitetsgrader i islam og til, at han underviste i private koranskoler i oplæsning af koranen. Både Omrane og Machfar havde deres egne programmer på Radio Zitouna. Mens Omrane udfyldte rollen i Radio Zitounas programmer som den ældre, vidende islamkyndige, var Machfar "det unge ansigt", der nok var islamkyndig, men som samtidig var mere uformel. Modsat Omrane talte Machfar altid på tunesisk dialekt, og hans programmer var fyldt med godt humør og latter. Machfars popularitet afspejler sig bl.a. på hans Facebook fanside, som i december 2010 havde 20.000 fans og over 161.000 i november 2012. Et andet ungt ansigt på radiostationen var på det tidspunkt Malika Gassam, som er i 20'erne, og som oprindeligt var en af Kamel Omranes studerende. I begyndelsen fungerede hun som Omranes assistent, men efterhånden stod hun selv for planlægning og gennemførelse af flere programmer, bl.a. de børneprogrammer, der blev sendt om søndagen.

Rollerne som professor og studerende opretholdt Kamel Omrane og Malik Gassem i et af de første programmer på Radio Zitouna, Al Kalima al-Taiba (Det gode ord). Programmets overordnede tema var, hvordan man skal opføre sig for at være en god muslim. I hvert program tog de forskellige aspekter af dette tema op, f.eks. hvordan man skal tale til venner og naboer, og hvordan man kan tænke og handle i overensstemmelse med islam. I programmet brugte Omrane referencer til koranen og hadith. Programmet udviklede sig som en dialog mellem de to, men som programmet skred frem, blev det tydeligt, at Kamel Omrane optrådte som den vidende professor, der underviser sin "studerende", Malika. I programmet spurgte Omrane hende omsorgsfuldt med mellemrum "er du med på, hvad jeg mener", som for at sikre sig, at hun kunne følge ham i samtalen. Men Omrane afprøvede også forsigtigt Malikas viden om islam ved f.eks. at spørge hende "hvem er det nu, Aicha er". Denne konstruktionen af en situation med en lærer og en elev viste sig 
gennem mine samtaler med Omrane at være en helt bevidst bestræbelse på at tage hånd om lytteren. Det var nemlig hensigten, at lytteren kunne identificere sig med Malika, som i programmet fremstå nysgerrig og interesseret men også uvidende. For Omrane var det nemlig sådan, tuneserne er: Bevidste om deres tro men uvidende. Dette skyldtes i hans optik den politik, som Bourguiba stod for. I Bourguiba-tiden var islam ifølge Omrane ikke helt fraværende men " Bourguiba var imod islam, og derfor er der opstået et hul i vores historie", forklarer han. Og det er netop her, han så Radio Zitouna have en vigtig opgave: "Vi her på radioen forsøger at forbinde nutiden men den fortid, der var, lige inden selvstændigheden, hvor islam stadig havde en central plads i Tunesien og for tuneserne", forklarede Omrane. Som en konsekvens af Bourguibas politik, hvor bl.a. de islamiske institutioner som beskrevet blevet lukket og de islamiske lærde fik meget begrænset råderum, mener Omrane, at der i årtier ikke har forgået en udveksling af viden mellem de lærde og tuneserne, og deraf er der opstået en mangel på viden. "Vi prøver at uddanne tuneserne fra bunden men meget langsomt, små skridt ad gangen. Lytterne skal ikke blive skræmte eller overfuses men lige så stille og roligt vænnes til at tænke og agere inden for rammerne af islam", siger Omrane og uddyber: "Radio Zitounas væsentlige rolle er at være der som en støtte for lytterne i en proces, hvor de langsomt lærer islam. Vi holder lytterne i hånden og leder dem gennem alle aspekter af islam”. Denne bro til fortiden bygges også ved hjælp af radiostationens navn. Som nævnt er "Zitouna" navnet på den historiske moske i Tunis og det tilhørende lærdomscenter, som blev lukket af Bourguiba som et led i hans sekulariseringspolitik. Anvendelsen af moskens navn insinuerer, at radiostationen er et tilsvarende lærdomssted med højtuddannede islamkyndige med særligt viden om bl.a. koranen og hadith, og navnet binder netop radiostationen sammen med fortiden, med det historiske lærdomssted. Udviklingen af forskellige genrer af programer på Radio Zitouna afspejler denne grundlæggende ide om, at der er et behov for at oplyse tuneserne, men at det må foregår med små skridt. I de første år omhandlede Radio Zitounas programmer først og fremmest, hvordan koranen, hadith og sunna skulle forstås, samt hvordan koranen skal oplæses korrekt (tajwid). Programmet Ta'lim al Quran al karim (Undervisning i den prægtige koran), hvor den ældre og velrenommerede Abderrahman al-Hafyane var studievært, er et eksempel på et tajwid-program. Det introducerer lytteren til de tekniske detaljer i recitetation af koranen. Men efterhånden blev også andre pro- 
gramtyper introduceret, så som programmet 'Ulama Tunis (Tunesiens islamiske retslærde), hvor Kamel Omrane var vært. Emnet i programmet var de store eller berømte ulama, der havde været ansat ikke blot ved Zitouna Moskeen men i hele Tunesien særligt i begyndelsen af 1900-tallet. Endvidere blev der introduceret spørge-programmer, hvor lytterne blev opfordret til at maile deres spørgsmål til radiostationen, og der kom korte indslag med radio-teater samt tre ugentlige børneprogrammer. Med de nye programmer var det Radio Zitounas intention at føre lytteren længere ind i islam, igen som en del af en større strategi, idet man gerne ville have tuneserne til at forstå, at islam ikke blot er en række teknikaliteter og grundtekster men også en måde at leve på i hverdagen. Som en af de kvindelige studieværter forklarede mig: "Vores religion lægger vægt på god opførsel og det ved folk, men de ved ikke hvordan de skal praktisere det til daglig”.

Hvordan islam kunne leves i hverdagen fik lytteren mange svar på i programmet Sou'al wa jawab (spørgsmål og svar). Programmet havde to studieværter: En kvinde, Sundus Hilali, der præsenterede sig som ustadha (lærer), og Doctor Mohamed Kaamil, som altså var doktor - det franske ord for en universitetsansat lektor eller professor. Sundus Hilali ledte programmet og læste de spørgsmål fra lytterne op. Doktor Kaamil besvarede disse spørgsmål. I en af udsendelserne fra 2009 var temaet bryllup og bryllupstraditioner, og i dette program var der fire spørgsmål fra lytterne som alle angik bryllupsritualer og islam. Efter at have budt velkommen og introduceret studieværterne, læste Sundus Hilali det første spørgsmål op. Det angik en af dagene i bryllupsritualet, hvor gommen skal give en gave til bruden, og spørgsmålet $1 \varnothing \mathrm{d}$, om det er et påbud i islamisk lov, sharia. Hertil svarede Doktor Kaamil blot bekræftende, at gommen skal give en gave, uden at den er overdrevet stor eller dyr, og afværgede dermed en nærmere udredning for sharia. Som beskrevet tidligere var afskaffelsen af islamiske love et helt cemtralt træk fra Bourguiba allerede de første år, han var ved magten, for at eliminere ulamas magt og rolle. Siden da har tunesisk lovgivning været civilretslig baseret, for selvom Ben Ali som beskrevet foretog flere islam-tiltag, ville en ændring til sharia-lov have ændret ved den adskillelse af stat og religion, der karakteriserer det sekulære Tunesien, og have åbnet en dør for den politiske islam, som Ben Ali netop bekæmpede. En offentlig diskussion af sharia har derfor været "en rød linie" - et emne, der ikke kunne tages op offentligt, da emnet var helt 
centralt for de to regimers magt. Derfor er det i netop en tunesisk sammenhæng bemærkelsesværdigt, at Sundus Hilali og Doktor Kaamil i det hele taget vælger at medtage et spørgsmål, der omhandler sharia. Selvom Doktor Kaamil ikke kommenterer den del af spørgsmålet yderligere, er der gjort et statement: Sharia optager lytterne, tuneserne, og tages alvorligt af Radio Zitouna - nøjagtigt som ulama ved det historiske lærdomscenter, Zitouna, ville have gjort.

I sådanne tiltag til at skubbe visse røde linier og bringe tabu-emner op har Radio Zitouna ligheder med de strategier, der gjorde sig gældende på andre, nye radio- og TV stationer i Tunesien. Mens TV og radio i Tunesien havde været statens monopol siden selvstændigheden, annoncerede Ben Ali i 2003, at mediesektoren nu var åben for private radio- og TV -kanaler. Dog skulle nye kanaler fortsat ansøge hos staten og have en tilladelse til at sende. To TV-kanaler og fem radio-kanaler blev lanceret fra 2003 og frem til regimeskiftet i januar 2011. Alle disse kanaler havde gennem ejerskabet tætte bånd til Ben Ali og hans nærmeste familie. Den første radiostation, der blev lanceret i 2003, var Radio Mosaïque FM, som var en del af holding firmaet Khartago Group, ejet af Ben Alis svoger, Belhassan Trabelsi. Endvidere var Radio Mosaïque FMs direktør, Noureddine Boutar, medlem af det medieråd, som Ben Ali oprettede i 1989, og som vejledte ham om politiske strategier inden for medieområdet. Således har ejerskab og ledelse af Radio Mosaïque FM og Radio Zitouna lighedspunkter: De var begge ejet af personer fra Ben Alis nærmeste familie, og den dalige ledelse blev forestået af medlemmer af de råd, der vejledte præsident Ben Ali om henholdsvis islam og medier. På flere måder var begge radiostationer således tæt knyttet til regimet. Men journalister og redaktører på Radio Mosaïque FM havde, som de ansatte på Radio Zitouna, klare ambitioner om, hvilken type radio de gerne ville lave, omend ambitionerne hér var nogle gangske andre end på Radio Zitouna. Radio Mosaïque FM ville være en radio for de unge i europæisk stil, med hurtige skift, masser af musik, en rap og fræk tone, og så ville man tage de emner op, der interesserede de unge, også selvom emnerne var tabu-belagte. Så længe programmerne ikke diskuterede præsidentfamilien og følsomme politiske emner - altså overtrådte bestemte røde linier - var der frihed til at skubbe grænser og bryde tabuerne (Haugbølle \& Cavatorta, 2012). I lighed hermed tog Radio Zitouna emner op, som hidtil ikke havde været i 
det offentlige rum sp som islam, tunesiske ulama, sharia, og hermed er radiostationen gennem sine de programmer der lød ud i æteren med til at skubbe grænserne for, hvad der taltes om offentligt.

Programmet om bryllupper, som Sundus Hilali og Doktor Kaamil præsenterede, ville imidlertid mere end at bringe tabuet sharia ud i æteren. Sundus Hilali går videre og præsenterer spørgsmål nummer to: Om det ikke er rigtigt, at der er en lille bøn, som profeten plejede at sige, og som man bør bede på sin bryllupsdag. Doktor Kaamil svarer, at der er en lille bøn, for at man kan påbegynde et nyt sikkert liv sammen, og han reciterede et eksempel på en sådan bøn. Herefter sagde Sundus Hilali: ”Ah, jeg har også selv lige et spørgsmål" - om der ikke er noget med, at gommen skal gøre noget inden brylluppet. "Jo", svarede Doktor Kaamil, "gommen skal bede to bønner inden bryllupsnatten". Sundus Hilalis eget spørgsmål fungerer som rollefordelingen mellem Kamel Omrane og Malika: I studiet er der en nysgerrig men uvidende, som repræsenterer tuneserne, sådan som i hvert fald Kamel Omrane opfatter og fremstiller dem i samtalerne med mig, og en lærd - her mænd, men der var andre programmer, hvor den lærde var en kvinde. Alle programmer på Radio Zitouna var nøje tilrettelagt og under mine besøg var det klart, at studieværterne ofte havde skrevet deres dialog ned inden optagelsen af et program. Gennem en sådan nøje tilrettelæggelse bliver det muligt i de enkelte programmer at opbygge et forløb, hvor man tilkendegiver og anerkender, at det er i orden, ikke at vide alt om islam, for Tunesien - repræsenteret igennem Radio Zitouna - rummer mange lærde, som kan give grundige og kyndige svar. Den nøje planlægning giver også mulighed for at udvælge, hvilke spørgsmål, der bringes op. Således er der sket en bevidst udvælgelse af bl.a. spørgsmålet om sharia.

Det fjerde og sidste spørgsmål angående bryllupritualer og islam, som blev taget op i programmet med Sundus Hilali og Doktor Kaamil, lyder om det er rigtigt, at brudeparret skal drikke et glas mælk sammen. I sit svar på dette spørgsmål lavede Doktor Kaamil en elegant kobling mellem islamiske foreskrifter og tunesiske traditioner, idet han svarede, at denne tradition med mælken "er en tunesisk tradition som kommer fra sunnaen" og han bekræftede dette med et eksempel fra hadith. Herefter sagde Doktor Kaamil kort, at "vi 
stopper her for i dag med spørgsmålene", og han afsluttede med at prise Guds alvidenhed. Mens lytteren med de tre første spørgsmål lige så langsomt blev ledt ind i en forståelse af islam som integreret del af brylluppet, kommer klimaks med fjerde spørgsmål. For mange tunesere vil ritualet med at drikke et glas mælk formentlig blive tilskrevet tunesisk, folkelig tradition men med ét gives det islamisk værdi, idet Doktor Kaamil, som allerede har markeret sin autoritet gennem bl.a. recitation af bøn, koblede denne tunesiske tradition med selve sunnaen. Dette efterlod lytteren med det indtryk, at de tunesiske traditioner således stammer fra sunnaen. Med ét knyttedes noget så folkeligt og velkendt af alle som bryllupppet helt tæt sammen med en af de primære kilder i islam, sunna, hvorved bryllupstraditionen nu fremstod med en helt ny dimension; islam. Og så var programmet slut, uden at der skabtes yderligere diskussion og forklaring eller blev inddraget flere uddybende spørgsmål. Radio Zitouna havde med denne udgave at Sou'al wa jawab fået leveret en række budskaber, bl.a. at islam er nem at udleve, fordi den allerede er en del af de traditioner, alle kender.

Sundus Hilali medvirkede også i et andet spørgeprogram, Fas'alou ahl al-dhikr (Spørg de religiøse lærde), hvor den islamkyndige var Sheikh Machfar. Også dette program tog spørgsmål op, som lytterne havde ringet ind med eller sendt på email. Sundus Hilali bød igen velkommen og fortalte, at en lytter ved navn Nedra fra byen Le Kef havde sendt et spørgsmål. Nedra var først for nylig begyndt at bede og spørger derfor til, hvordan hun kan nå alle dagens bønner, når hun også går på arbejde. På sin meget dagligdags facon svarede Machfar: "Du slår simpelthen bare to fluer med et smæk og beder bønnerne på en gang, enten om morgenen eller om aftenen. Det er det, der hedder indhentningsbønner (qadha). Der er folk, der har tid (til bønner). Men så er der folk, der ikke har tid, og de kan foretage indhentningsbønner på hvilket som helst tidspunkt, det skal være”. Af og til giver Machfars folkelighed sig ikke kun til udtryk i hans sprogbrug men også i de råd, han kommer med. På et spørgsmål om, hvordan en lytter kan blive stærkere i sin tro, svarede han: "(...) Der var andre ulama, som sagde: "put vand eller juice i en lille beholder og put så fingeren ned i det mens du siger "vis mig den rette vej" 70 gange, og så drikker du vandet, og så vil Allah hjælpe dig" ". Machfars råd har ligheder med Kaamils inddragelse af eksemplet med at drikke mælk på bryllupsnatten. Begge angår de en populær is- 
lam, som er del af daglig praksis blandt tuneserne. I stedet for at irettesætte lytterne og fortælle dem, at dette er overtro eller en populær praksis, imødekommer Radio Zitouna disse traditioner og inkluderer dem i det, der er den særlige tunesiske islam. For som Kamel Omrane har forklaret, så er målet jo netop ikke at støde lytterne fra sig ved at irettesætte dem men snarere at trække lytterne til, så man langsomt kan indføre dem i islam.

For Radio Zitouna er det først og fremmest centralt, at radioprogrammerne skal oplære, uddanne og opdrage tuneserne i islam og i, hvordan religionen kan praktiseres, både $\mathrm{i}$ hverdag og fest. Mann vil "bygge bro" over hullet skabt af Bourguibas politk, som Omrane forklarer. Men dernæst er det centralt for Radio Zitouna at forankre islam i en specifik, tunesisk kontekst og i programmerne demonstreres det, hvordan islam er en kerne-del af tunesisk identitet og historie, herunder de tunesiske ulama før Bourguiba-tiden, hvis historie og virke behandles i programmet "Ulama Tunis". Den tunesiske islam, som Radio Zitouna formulerer, er tolerant og moderne, hvilket også blev gjort tydeligt med radioens slogan fra lanceringen, som lød: "Tolerance, broderskab og mådehold”. Det særlige tunesiske element af islam understreges af, at der i alle programmer undtagen nogle få, som er på fransk, anvendes tunesisk dialekt i stedet for klassisk arabisk, som ellers ofte anvendes i islam-sammenhænge. Dialekten understøtter fremstillingen af en det særlige tunesiske. Derudover understreger dialekten, at islam er et dagligdags fænomen, som ikke er forbeholdt særligt højtstående retslærde og dem, der kan læse og tale klassisk arabisk. "Islam er nemt", gentager Kamel Omrane både i sine programmer og i interviews, "islam kræver ikke særlig sprogbrug eller særlige forudsætning, islam er dagligdags”.

Denne italesættelse af en "tunesisk islam" forklarer Omrane i samtalerne med mig som "et modsvar til den islam der kommer fra Golfen". Han påpeger, at den tunesiske islam i modsætning til islam fra Golfen er rummelig over for forskelligheder, åben over for videnskab og giver enhver ret til at leve sit liv, som han eller hun vil det. For ham er det særligt nødvendigt at minde om den tolerante, tunesiske islam fordi: "Terrorismen er vores største fjende". Som jeg redegjorde for tidligere, skete der året før Radio Zitounas lancering en ændring af islam-billedet i Tunesien 2006. Regimett satte i ramadanen ind mod kvindernes brug af hijab, og i sin ramadantale i 2006 sagde Ben Ali at tørklædet ik- 
ke var en del af den tunesiske tradition men et fremmedelement fra udlandet. Kort tid efter pågreb man den bevæbnede gruppe tæt på Tunis, med relationer til udenlandske salafistiske jihad-grupper. Terrorisme blev med ét nærværende i Tunesien. Der er således både i regimet og hos Kamel Omrane en opmærksomhed på den internationale kontekst, Tunesien befinder sig i, og som opleves som en trussel, som det er nødvendigt at respondere på. Inden for disse rammer er det oplagt at konkludere, at regimet lancerede Radio Zitouna for at opgradere og konsolidere egen magt og monopolet på islam-området gennem denne opgradering. Yderligere perspektiver må dog tilføjes denne konklusion. Jeg skal diskutere dette i det følgende.

\section{Ejerskab eller individer?}

Udganspunktet for denne artikel var spørgsmålet, om Radio Zitouna var en "regimeradio", som var lanceret som et tiltag fra det autoritære regime for at styrke egen magt. Teoretiske debatter om og analyser af de arabiske autoritære regimer fra begyndelsen af 2000-tallet har argumenteret for, at sådanne tiltag igangsættes af regimet for at opgradere sin magt på et område, hvor det føler sig truet. (Albrecht \& Schlumberger, 2004). Hvis fokus alene holdes på årene 2006 og 2007 synes denne forklaring at passe på spørgsmålet om Radio Zitounas lancering. Den tunesiske befolkning manifesterede i denne periode i stadig stigende grad deres praktiseren af islam offentligt ved bl.a. at bære hijab og bede $\mathrm{i}$ moskeerne, og der synes således at have været en modstand mod regimets begrænsende islampolitik i befolkningen. Endvidere kan tilstedeværelsen af en terrorgruppe med tilknytning til islam ses som en trussel mod regimets magt, da regimet både over for Vesten og tuneserne havde lanceret sig som en garant mod terror og uro i landet. Lanceringen af en islamisk radiostation ejet af Ben Alis svigersøn og dermed med en tæt tilknytning til regimet kan ses som det autoritære regimes bestræbelse på at navigere i de ændrede islamforhold. Med en islamisk radiokanal kunne regimet imødekomme befolkningens $\emptyset$ gede fokus på islam. Endvidere kunne man gennem radiostationen understrege budskabet om tolerance og dermed fortsat fremstille sig som garant mod voldelig terror. 
Imidlertid viser analysen af programmerne på Radio Zitouna suppleret med samtalerne med Kamel Omrane og andre ansatte, at der for dem var en dybereliggende årsager til deres arbejde, engagement og de budskaber, de bragte gennem programmerne, end blot opbakning til det autoritære regime, og respons på den tilspidsede situation i 2006-2007. Disse årsager knytter sig til en større historisk og politisk kontekst. For selvom Kamel Omrane henviste til terrorisme, var det fraværet af islam skabt i Bourguiba-perioden fra 1956, som Omrane kredsede om i samtalerne, og det var omdrejningspunktet i flere af programmerne på forskellig vis. Gennem programmet 'Ulama Tunis' genoplivede Omrane den for ham gyldne fortid inden selvstændigheden og Bourguibas eliminering af de islam-lærde. For ham havde elimineringen haft den konsekvens, at tuneserne ikke havde kunne opnå viden om islam. Han så det derfor som radiostationens centrale opgave at råde bod på dette fravær af læring og langsomt føre tuneserne længere og længere ind i forståelsen af islam, og af hvordan islam kunne udleves i det aktuelle, tunesiske samfund. Dette hjalp Omrane dem med i rollen som den tålmodige, vidende professor, der kærer sig for sine studerende - tuneserne eksemplificeret gennem Malika. Som analysen viser, var Omrane ikke den eneste med dette synspunkt. Flere af de kvindelige studieværter udtrykte en ambition om, at tuneserne ikke blot skulle kende koranen og hadith men blive bedre til at udleve islam i hverdagen, så samfundet langsomt blev mere gennemsyret af en moralsk levevis i overensstemmelse med islam. Endvidere gjorde Doktor Kaamil og Sheikh Machfar sig bestræbelser på at koble islam med både en tunesisk fortid og med nutiden. Men mens Omrane ofte betonede det historiske, var Doktor Kaamil og Sheikh Machfar optaget af traditionerne, den populære islam og i at møde tuneserne dér, hvor de er: Til fest og i deres daglige praksis af islam, f.eks. bøn.

Hermed skete der snarere det modsatte af det, som teorien om regimerns opgradering hævder. Radio Zitouna var ikke kun talerør for regimet. Snarere var Omrane, Machfar, Kaamil og de øvrige ansatte på Radio Zitouna med til at skubbe på en igangværende islam-udvikling, hvor islam var blevet endnu mere tydelig i offentligheden og en del af folks daglige praksis. Netop det, der med udgangspunkt i teorien og hændelserne i 20062007 kunne ses trusler mod regimet, som man derfor forsøgte at nedtone, kooptere eller eliminere gennem forskellige tiltag, heriblandt lanceringen af Radio Zitouna. Men hvis 
dette var tilfældet, var der ikke overensstemmelse mellem regimets strategi og det, de ansatte på radiostationen arbejdede for. Denne uoverensstemmelse er her blevet eksemplificeret med spørgeprogrammet med Sundus Hilal og Doktor Kaamil, hvor de to studieværter havde valgt at bringe et spørgsmål om sharia op. Som beskrevet har sharia netop være "en rød linie", et emne, som ikke har kunne diskuteres offentligt under hverken Bourguiba eller Ben Ali. Men Radio Zitouna udfordrede altså dette tabu ved bevidst at udvælge spørgsmålet til programmet. Gennem sådanne små valg var Radio Zitouna snarere var med til at skubbe på og udfordre grænserne for, hvilke islam-emner der kunne tales om i en tunesisk offentlighed, end til at konsolidere regimet.

Som det er tilfældet for Radio Mosaïque FM var ejerskabet og de ledende personligheder på Radio Zitounas nære forhold til Ben Ali netop med til at skabe sikre rammer, idet radiokanalen ikke var del af en illegal opposition men netop et medie tæt knyttet til regimet. Men denne sikre ramme gav samtidig de ansatte en mulighed for at udlægge egne aspekter af islam og religionens rolle i Tunesien, og denne udlægning var ikke på alle punkter i overensstemmelse med den officielle regime-retorik. Svaret på spørgsmålet om relevansen af ejerskabet for at forstå lanceringen af Radio Zitouna peger gennem programanalyser og samtaler med de ansatte i retning af, at Radio Zitouna frem for at være regimets talerør snarere skal ses som en monolit: Radio Zitouna har løsrevet sig "moderfjeldet”, regimet, og er blevet en selvstændig klippeblok. Under oprøret i december 2010, vendte Kamel Omrane imidlertid tilbage til "moderfjeldet", da han tiltrådte som minister for religiøse anliggender. Hermed rejser der sig et nyt spørgsmål om, hvem og hvad "regimet” var. For både Kamel Omrane og Sheikh Machfar på Radio Zitouna og deres kollega Noureddine Boutar på Radio Mosaïque FM havde centrale poster tæt på præsidenten og var dermed personer, der i teoretiske diskussioner af de arabiske autoritære regimer ville blive anset som "kerne-eliter" (core elites, Perthes, 2004). Men det forhold, at de anvendte disse positioner til at skabe monolitiske frirum, hvor de kunne udleve egne ambitioner og ideer, der ikke altid var i overensstemmelse med den officielle regime-linie, antyder, at "regimet" ikke var én stor enhed, hvor alle travede i takt. Snarere peger analysen af Radio Zitouna på, at bag præsidentfamilien var der en række af enkeltpersoner med egne politiske og ideologiske agendaer. Efter oprøret er dette forhold blevet endnu 
tydeligere. Kamel Omrane etablerede i foråret 2011 et politisk parti, som især betonede en mere fremtrædende plads for islam i det nye Tunesien. Partiet opstillede til valget til Grundlovsforsamlingen i oktober 2011. Sheikh Machfar fik i januar 2011 overdraget ledelsen af Radio Zitouna, og senere på året tog han et voldsomt opgør med den venstreorienterede elite inden for det islamstudier og teologi på de sekulære universitet, der i sin tid blev oprettet af Bourguiba i stedet for lærdomscenteret ved Zitouna Moskeen. Men Omrane, Machfar og Boutar var tilsyneladende ikke de eneste, der nok var tætte på regimet, men som havde egne ambitioner for Tunesien. I den konstant foranderlige transitionsproces, som Tunesien gennemgår, træder stadig flere enkeltpersoner med både nære og løse bånd til regimet i karakter som politiske aktører. I denne artikel er der sat fokus på nogle af disse aktører, som trådte i karakter allerede inden oprøret. Men tilsvarende studier vil kunne foretages af andre aktiviteter med tilknytning til regimet i Tunesien såvel som i andre arabiske lande, hvormed ikke blot en mere nuanceret forståelse af landene under de autoritære ledere fremstår, men også en forståelse for de personer, der nu træder ind på scenen som aktører i transitionsprocesserne.

\section{Litteratur}

Albrecht, H. \& Schlumberger, O., 2004: "'Waiting for Godot', Regime Change Without Democratization in the Middle East", International Political Science Review, Vol. 25, No. 4

Alexander, Christopher, 2011: Tunisia's protest wave: where it comes from and what it means", Foreign Policy, 3. Januar

Allani, A., 2009: 'The Islamists in Tunisia between Confrontation and Participation: 1980-2008', Journal of North African Studies, 14/2, pp. 257-272.

Ayachi, Nejib, 2011: "Remarks on the unfolding of the events, and the nature of Tunisia's political regime", indlæg på konferencen "The Breakdown of Autocracy in Tunisia", The Maghreb Center, Washington, 9. februar, tilgængeligt på www.maghrebcenter.org

Boulby, Marion, 1988: "The Islamic Challenge: Tunisia since Independence”, Third World Quarterly, Vol 10, No. 2 
Charrad, Mounira, 2011: "Tunisia at the forefront of the Arab world: two waves of gender legislation", in ed. Sadiqi, Fatima and Ennaji, Moha, 2011: Women in the Middle East and North Africa, Routledge

Charrad, Mounira, 2001: States and women's rights, the making of postcolonial Tunisia, Algeria and Morocco (London: University of California Press)

Erdle, S., 2010: Ben Ali's 'New Tunisia' (1987-2009). A Case Study of Authoritarian Modernization in the Arab World (Berlin, Klaus Schwartz Verlag).

Hajji, Lotfi, 2011: Bourguiba et l'Islam. Le politique et le religieux, Sud Éditions, Tunis Haugbølle, Rikke Hostrup, 2011: " "Familien” og nye private medier i Tunesien", Tidsskriftet Babylon, No. 2

Haugbølle, Rikke Hostrup, 2006: "Tunesiens indirekte arv fra det franske protektorat", i Tidsskriftet Babylon, Oslo, marts

Haugbølle, Rikke Hostrup and Cavatorta, Francesco, 2012: "'Vive la grande famille des médiasTunisiens". Media reform, authoritarian resilience and societal responses in Tunisia”, Journal of North African Studies, Vol. 17, No.1

Haugbølle, Rikke Hostrup and Cavatorta, Francesco, 2011:"Will the real Tunisian opposition please stand up?", British Journal of Middle East Studies, Vol. 38, No. 3, December

Heydemann, S., 2007: "Upgrading authoritarianism in the Arab world", The Brookings Institution, Analysis Paper, 13, 1-37. Available at http://www.brookings.edu/ /media/Files/rc/papers/2007/10arabworld/10arabworld.pdf.

Hibou, Béatrice, 2006: La force de l’obéissance, Découverte, Paris

Hinnebusch, R., 2006: "Authoritarian persistence, democratization theory and the Middle East: An Overview and Critique”. Democratization, 13, 373-395.

Kerrou, Mohamed, 2010: Hijâb. Nouveaux voiles et espaces publics, Ceres Editions, Tunis

Khlifi, Omar, 2005: L’assassinat de Salah Ben Youssef, MC Editions, Tunis

King. S., 2003: Liberalization against democracy, Bloomington: Indiana University Press

Moore, Clement Henry, 1965: Tunisia since Independence. The Dynamics of One-Party, Government, University of California Press 
Murphy, Emma, 2011: "The Tunisian Uprising and the Precarius Path to Democracy", in Mediterranean Politics, Vol. 16, No. 2, 299-305, July

Perkins, Kenneth J., 2004: A History of Modern Tunisia, Cambridge University Press.

Perthes, Volker, ed., 2004: Arab Elites: Negotiating the Politics of Change, Lynne Rienner Publications

Salem, Norma, 1984: Habib Bourguiba, Islam and the Creation of Tunisia, Routledge Kegan \& Paul

Valbjørn, Morten, 2007: "Studiet af demokratiets (ir)relevans i et (u)almindeligt Mellem$\varnothing$ sten - om фrkenvandringer, fatamorganaer, ørkenblomster og om at vandre i cirkler", Politica, 39. årg., nr. 2

Waltz, Susan, 1986: "Islamist Appeal in Tunisia", Middle East Journal, vol. 40, 4 autumn

\section{Forfatterpræsentation}

Rikke Hostrup Haugbølle er ph.d. stipendiat i forskningsprojektet "Nye islamiske offentligheder" på Institut for Tværkulturelle og Regionale Studier, Københavns Universitet. I det igangværende forskningsprojekt analyserer hun nye udtryk for islam og de nye private tunesiske mediers rolle fra 1987 til 2011. Hun har publiceret i en række internationale tidsskrifter, bl.a. Journal of North African Studies og Mediterranean Politics, og bidraget med kapitler til bøger. Efter oprøret i Tunesien i 2011 har hun været ekstern konsulent for Udenrigsministeriet og for en række danske og internationale NGO'er.

\footnotetext{
${ }^{\mathrm{i}}$ Det tunesiske magasin Leaders bragte i december 2011 en stærk artikel om den nuværende premierminister fra Ennahda Hamadi Jebalis fængslinger, exil og overvågning gennem 17 år. Artiklen er tilgængelig på http://www.leaders.com.tn/article/retour-sur-leparcours-politique-de-hamadi-jebali?id=7198, sidst læst 20.06.2012
} 